\title{
Sağlık Harcamaları ve Çevre Kirliliği: ASEAN-5 Ülkeleri Üzerine Bir Panel Veri Analizi
}

\section{Dr.Öğr. Üyesi Yasemin Dumrul ${ }^{1^{*}}$}

Geliş tarihi: 27.08.2019

Kabul tarihi: 20.09.2019

\section{Atuf bilgisi:}

IBAD Sosyal Bilimler Dergisi

Sayı: Özel Sayı Sayfa: 396-407

Yıl: 2019

This article was checked by iThenticate. Similarity Index $15 \%$.

${ }^{1}$ Kayseri Üniversitesi, Türkiye, ydumrul@kayseri.edu.tr, ORCID ID 0000-0001-5961-2931

* Sorumlu yazar öz

Sağlığı etkileyen ve kötüleşen bir çevre ekonomik faaliyetler üzerinde olumsuz bir etkiye yol açabilmektedir. Bu çalışmada çevre kirliliğinin ve ekonomik büyümenin sağlık harcamaları üzerindeki etkisi ASEAN-5 ülkeleri için 2000-2014 dönemi ele alınarak incelenmiştir. Çalışmada Pedroni, Kao ve panel FMOLS eş-bütünleşme testleri uygulanmıștır. Çalıșma sonucuna göre sağlık harcamaları, çevre kirliliği ve ekonomik büyüme arasında uzun dönemli bir ilişki bulunmaktadır. Ayrıca çalışmada çevre kirliliği ve ekonomik büyümenin sağlık harcamalarını artırdığı bulgusuna da ulaşılmıştır.

Anahtar Kelimeler: Sağlık Harcamaları, Çevre Kirliliği, Ekonomik Büyüme, Panel Eş-bütünleşme Testi 
Health Expenditures and Environmental Pollution: A Panel Data Analysis on ASEAN-5 Countries

Assist. Prof. Dr. Yasemin Dumrul ${ }^{1^{*}}$

First received: 27.08 .2019

Accepted: 20.09.2019

\section{Citation:}

IBAD Journal of Social Sciences

Issue: Special Issue Pages: 396-407

Year: 2019

This article was checked by iThenticate. Similarity Index $15 \%$.

${ }^{1}$ Kayseri University, Turkey, ydumrul@kayseri.edu.tr,

ORCID ID 0000-0001-5961-2931

* Corresponding Author

\begin{abstract}
An environment that affects and deteriorates health can have a negative impact on economic activities. In this study, the effect of environmental pollution and economic growth on health expenditures is investigated by examining the period 2000-2014 for ASEAN-5 countries. In this study, Pedroni, Kao and panel FMOLS co-integration tests were applied. According to the results of the study, there is a long-term relationship between health expenditures, environmental pollution and economic growth. In addition, it was found that environmental pollution and economic growth increased health expenditures.
\end{abstract}

Keywords: Health Expenditures, Environmental Pollution, Economic Growth, Panel Co-integration Test. 


\section{GİRIŞ̧}

Küresel ısınma ve sera gazı emisyonlarının çevresel sonuçları, fosil yakıtların tüketimiyle ilgili endişeleri artırmaktadır. Nüfus artışı, trafik ve endüstriyel faaliyetlerin yoğunlaşması kirleticilerin kullanımının fazlalaşmasına ve dolayısıyla maruz kalınan çevresel risklerin artmasına yol açmaktadır (Yazdi vd., 2014, s. 126). Negatif dişsallık olarak da ifade edilen bu çevresel riskler insan sağlığını olumsuz etkileyerek, çeşitli hastalık türlerinin (morbidite) ortaya çıkmasına ve ölümlere (mortalite) sebebiyet verebilmektedir (Erden ve Turan Koyuncu, 2014, s. 13). Dünya Sağlık Örgütü (WHO) (2009) raporuna göre, çevresel faktörlerin, ölüm ve hastalık gelişimine katkısı kesin olarak belirlenemese de, yılda on üç milyon ölümün önlenebilir çevresel nedenlere bağlı olduğu tahmin edilmektedir. Ayrıca raporda, gelişmekte olan ülkelerde çevrenin sağlık üzerindeki etkilerinin gelişmiş ülkelere göre çevresel risklere maruz kalma ve sağlık hizmetlerine erişimdeki farklılıklar nedeniyle 15 kat daha yüksek olduğunu tahmin edilmektedir (Remoundou ve Koundouri, 2009, s. 2161).

Sera gazı emisyonlarının artması çevre ve insan sağlığı için ciddi bir risk oluşturmaktadır (Apergis vd, 2018a, s. 1011). Çevre, insan sağlığı üzerinde geleneksel ve modern olmak üzere iki tür risk yaratmaktadır. Geleneksel riskin etkileri kısa sürede görülmekte, ekonomik kalkınmanın sağlanamamasından kaynaklanmakta ve yoksulluk ile ilişkilendirilmektedir. Modern riskler ise etkileri zamanla ortaya çıkan ve hızlı ekonomik kalkınmadan kaynaklanan hava ve su kirliliği olarak ifade edilmektedir (Erden ve Turan Koyuncu, 2014, s. 13).

Çevre kirliliği insan sağlığını, insanları doğrudan zararlı maddelere maruz bırakarak ya da dolaylı olarak ekosistemleri bozarak etkilemektedir (Zaidi ve Saidi, 2018, s. 2). Bunun yanı sira insan sağlığını olumsuz bir şekilde etkileyen çevre kirliliğinin işgücü verimliliğine olumsuz yansımaları söz konusudur (Yazdi vd., 2014, s. 127). Şöyle ki, sağlık, beşeri sermayenin kalitesini belirleyen en önemli faktörlerden biridir (Abdullah vd., 2016, s. 27; Yazdi vd., 2014, s. 127). İktisadî büyüme teorilerinde, beşeri sermayenin büyüme süreci için önemli bir rol oynadığı ileri sürülmektedir. Ekonomi literatüründe beşeri sermaye kavramı; eğitim, sağlık, iş eğitimi, göç ve bireyin verimliliğini artıran diğer yatırımları da içerecek şekilde tanımlanmıştır (Akram vd., 2008, s. 487). Dolayısıyla sağlıklı olma, beşeri sermayenin verimlilik seviyesinin artmasına katkıda bulunurken çevre kirliliği, insan sağlığını olumsuz bir şekilde etkileyerek işgücü verimliliğinin ve işgücü arzının azalmasına yol açmaktadır. Belirtilen durum, endüstriyel çıktıyı ve ulusal üretimi etkilemekte, böylece firmaların ve ekonominin büyümesi de etkilenmektedir (Narayan ve Narayan, 2008, s. 367-368). Özetle, çevre kirliliği insan sağlığı için bir risk oluşturmakta ve bu durum da ekonomik büyümenin azalmasına yol açabilmektedir (Chaabouni vd., 2016, s. 185). Bu bağlamda, sağlık, ekonomik büyüme ve çevre kirliliği arasında dinamik bir ilişkinin varlığını destekleyen güçlü ampirik kanıtlar söz konusudur.

Toplumların gelişmişlik düzeyleri ile sağlık arasında yakın bir ilişki bulunmaktadır. Nitekim gelişmişlik düzeylerini belli bir seviyeye getirebilmiş olan toplumlarda hem GSYİH'den sağllğa ayrılan payın hem de sağlık için yapılan harcamaların arttığı görülmektedir (Selim vd., 2014, s. 14). Daha iyi sağlık hizmetleri ile teknoloji ve kentleşme vasıtasıyla dünyadaki doğurganlık hızı azalmakta ve yaşam beklentisi artmaktadır. Doğurganlık oranının düşmesi ve yaşam beklentisinin artması, toplam nüfus içerisinde yaşlıların payında artışa yol açmaktadır. Genç kuşağın, artan sayıda yaşlı aile ve aile üyesini destekleyemeyeceği düşünüldüğünden nüfus yaşlanması, geleneksel sosyal koruma sistemleri üzerinde bir baskı yaratmaktadır. Hükümetler, toplumdaki gelirin nasıl dağıtılacağının, yaşlıların gelir güvenliğinin ve yeterli sağlık hizmetlerinin nasıl sağlanacağı konusundaki zorluklarla karşı karşıya kalmaktadır. Bu nedenle hükümetlerin sağlık, sosyal güvenlik, emekli aylıkları ve sosyal yardım gibi hizmetlere ne kadar harcama yapmaları gerektiğinin belirlenmesi önem arz etmektedir (Sagarik, 2016, s. 2-6).

Günümüzde sağlık harcamalarının belirleyicileri hem gelişmiş hem de gelişmekte olan ülkelerde incelemeye konu olmaktadır. Sağlık harcamalarının belirleyicileri; gelir, nüfus, yaşam tarzları, dış yardım miktarı, kamu tarafından finanse edilen sağlık hizmetleri oranı, kadınların işgücüne katılım oranı, pratisyen hekim sayısı, kentleşme oranı, okuryazarlık, teknolojik ilerleme ve çevresel faktörler olarak ifade edilmektedir (Abdullah vd., 2016, s. 27; Yazdi vd., 2014, s. 127; Narayan ve Narayan, 2008, s. 367; Murthy ve Okunade, 2016, s. 68; Yazdi ve Khanalizadeh, 2017, s. 1182). Çevre 
kirliliğinin kaynağı ise, kirlilik ve gürültüdür (Yazdi vd., 2014, s. 127). Karbondioksit $\left(\mathrm{CO}_{2}\right)$, metan gazı $\left(\mathrm{CH}_{4}\right)$, azot dioksit $\left(\mathrm{NO}_{2}\right)$, hidrokarbonlar ve klorakarbonlar çevre kirliliğine yol açan ve atmosferde en fazla bulunan sera gazları arasında yer almaktadır. Belirtilen kirleticilerin sera gazı oluşumuna katkıs1 şu şekildedir: $\mathrm{CO}_{2}-\% 72$, metan-\%18, $\mathrm{NO}_{2}-\% 9$, hidrokarbonlar ve klorakarbonlar (düşük oranlarda) (Sileem, 2016, s. 67). Dolayısıyla çevre kirliliğine en fazla katkısı olan faktör karbondioksit emisyonudur. Fosil yakıt yanması, toprak erozyonu ve ormansızlaşma gibi çeşitli nedenlerden kaynaklanan karbondioksit emisyonu, mevcut ve uzun vadeli çevre kalitesinin belirlenmesinde önemli bir rol oynamaktadır (Apergis vd., 2018b, s. 522). Ayrıca, çevre kirliliği hükümet bütçeleri üzerinde de artan baskı yaratmakta, potansiyel olarak artan sağlık harcamalarına yol açmaktadır (Narayan ve Narayan, 2008, s. 367-368; Yazdi ve Khanalizadeh, 2017, s. 1182). Başka bir ifadeyle çevre kirliliğinin yol açtığı sağlık sorunları, sağlık harcamalarını daha da artırarak ülke ekonomileri üzerinde ağır yükler oluşturabilmektedir. Çevresel bozulmanın neden olduğu sağlığını kaybetme riski ile karşı karşıya olan kişi sayısı arttıkça, hükümetler daha fazla mali kaynağa ihtiyaç duymaktadır. Bununla birlikte özellikle gelişmekte olan ülkelerde büyük ölçüde, yabancı sermaye yatırımlarından ve ithal girdiye bağlı olarak yapılan ihracattan elde edilen kazançlar ile gelir artışı sağlanabildiğinden insan sağl 1 ğı üzerinde ciddi ve kronik etkileri olan çevre kirliliğini azaltmaya yönelik çevresel düzenlemeler çok fazla dikkate alınmamaktadır.

Bu çalışmanın amacı çevre kirliğinin ve ekonomik büyümenin sağlık harcamaları üzerindeki etkisinin yoğun doğrudan yabancı sermaye girişleri, yüksek ihracat ve büyüme oranları ile dünya ekonomisinde önemli bir yere sahip olan Güneydoğu Asya Uluslar Birliği'nin (ASEAN) beş ülkesi (ASEAN-5) örneğinde incelenmesidir. Çalışmanın geri kalan kısmına ilişkin plânı şu şekildedir. Çalışmanın ikinci bölümünde ASEAN-5 ülkelerinde sağlık harcamaları ve çevre kirliliği ile ilgili bilgi verilecektir. Üçüncü bölümde konuya ilişkin uygulamalı literatür sunulacaktır. Dördüncü bölümde çalışmada kullanılan veri ve model açıklanacaktır. Beşinci bölümde çalışmada kullanılan yöntem ortaya konulacak ve analiz sonuçları sunulacaktır. Son bölümde ise, çalışmanın sonuç bölümüne yer verilecektir.

\section{ASEAN-5 ÜLKELERINDE SAĞLIK HARCAMALARI VE ÇEVRE KİRLİLİĞİ}

İyi bir sağlığa sahip olma mikroekonomik açıdan kişilerin gelirlerinin artmasına katkıda bulunurken, makroekonomik açıdan da ekonomik büyümeyi desteklemektedir. Gelir düzeyindeki artış, halkın sağlık koşullarını iyileştirmektedir. Ayrıca, ekonomik büyüme sadece daha yüksek gelire değil, aynı zamanda daha yüksek bir yaşam kalitesine yol açmakta ve böylece sağlık koşullarının iyileştirilmesi sağlanmaktadır (Lu vd., 2017, s. 136). Bununla birlikte ASEAN-5 ülkelerinde küreselleşme derecesi arttıkça, sosyal koruma son yıllarda önemli bir kamu politikası konusu haline gelmiştir. Küreselleşme baskısının yanı sıra, bazı ASEAN ülkeleri nüfusun yaşlanması baskısıyla karşı karşıya kalmıştır. (Sagarik, 2016, s. 2). Şekil 1'de ASEAN-5 ülkelerinde sağlık harcamalarının GSYİH'ye oranı gösterilmiştir.

Şekil 1: ASEAN-5 Ülkelerinde Sağlik Harcamalarının GSYİH'ye Oranı (\%)

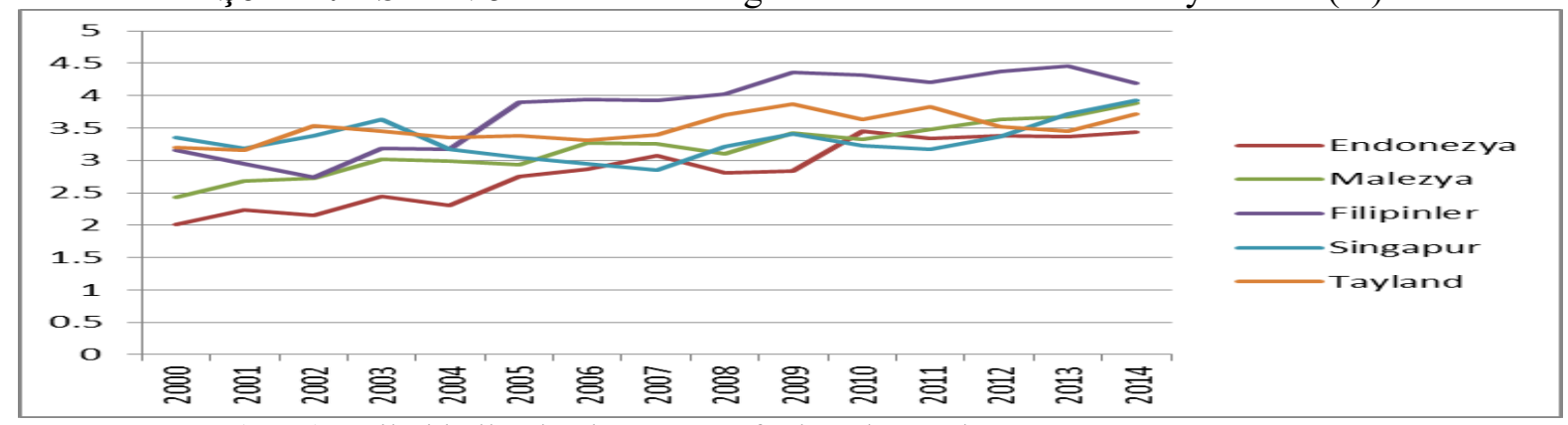

Kaynak: WDI (2018) verileri kullanılarak yazar tarafından oluşturulmuştur.

2000 yılında sağlık harcamalarının GSYİH'ye oranı Endonezya'da \%2, Malezya'da \%2,43, Filipinlerde \%3.15, Singapur' da \%3.35 ve Tayland'da \% 3.19 iken 2014 yılında Endonezya'da \%3.44 Malezya'da \%3.89, Filipinlerde \%4.19, Singapur'da \%3.93 ve Tayland'da \% 3.19'a yükselmiştir. Güneydoğu Asya ülkelerinde yıllar itibariyle sağlık harcamalarının GSYİH’ye oranı artmıştır. 
Güneydoğu Asya ülkeleri hızlı ekonomik büyüme, nüfus artışı ve enerjide yüksek oranda dışa bağımlılığın yol açtığı ciddi bir çevre problemi ile karşı karşıya bulunmaktadır. ASEAN bölgesinde hava kirliliği artmakta, enerji sektöründen kaynaklanan karbondioksit emisyonları bu durumun en büyük sorumlusu olarak gösterilmektedir. Bununla birlikte ASEAN bölgesinde enerji kaynaklı $\mathrm{CO}_{2}$ emisyonu seviyelerinin 2014 yılından 2025 yılına kadar \%61 oranında yükseleceği tahmin edilmektedir. Belirtilen duruma en önemli katkı kara ve orman yangınlarından kaynaklanan ve sınır aşan pus kirliliğidir. Sınır aşan duman pusunun \% 90'1 büyük ölçekli ticari plantasyonların yayılmasıyla ilgili turba yangınları ile bağlantılıdır. 1990 ve 2012 arasında, çoğu ASEAN ülkesi, özellikle kauçuk ve palm yağı elde edilmesi için yapılan ticari plantasyonların orman alanlarına yayılmasından dolayı, orman örtüsünde bir düşüş yaşamıştır (Fifth ASEAN State of the Environment Report, 2017, s. 18). Ayrıca, kentleşmede yaşanan artış da enerji tüketiminin ve dolayısıyla $\mathrm{CO}_{2}$ emisyonunun artmasına yol açmıştır. Şekil 2'de ASEAN-5 ülkeleri için $\mathrm{CO}_{2}$ emisyonu değerleri verilmiştir.

Şekil 2: ASEAN-5 Ülkelerinde $\mathrm{CO}_{2}$ Emisyonu (metrik ton)

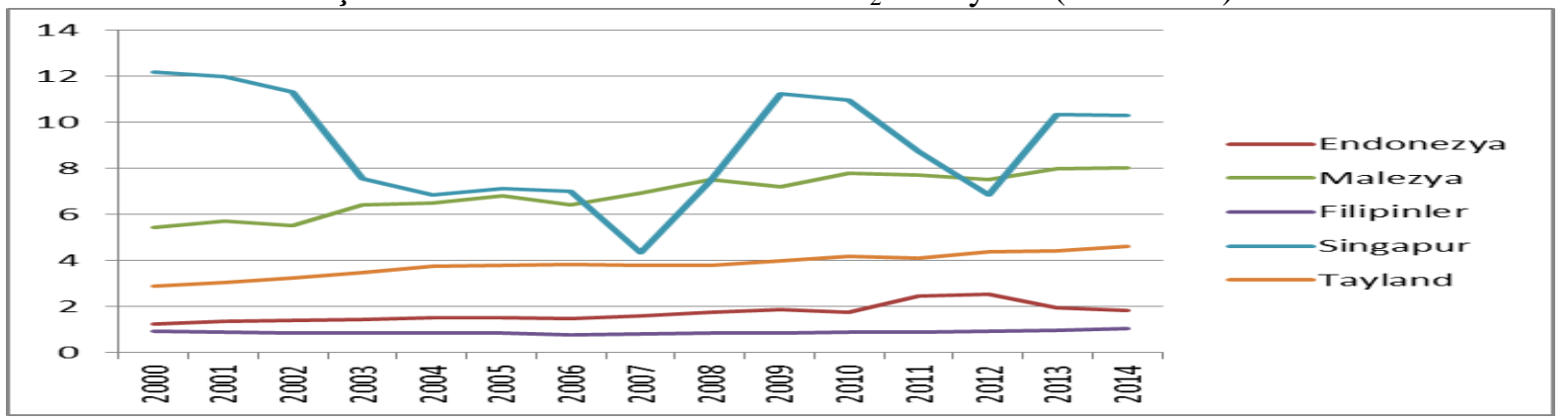

Kaynak: WDI (2018) verileri kullanılarak yazar tarafindan oluşturulmuştur.

2000 yılında $\mathrm{CO}_{2}$ seviyesi Endonezya'da kişi başına 1.24 metrik ton (mt), Malezya'da kişi başına 5.42 $\mathrm{mt}$, Filipinlerde kişi başına $0.93 \mathrm{mt}$, Singapur'da kişi başına $12.2 \mathrm{mt}$ ve Tayland'da kişi başına 2.88 mt iken 2014 Endonezya'da kişi başına $1.82 \mathrm{mt}$, Malezya'da kişi başına $8.03 \mathrm{mt}$, Filipinlerde kişi başına $1.06 \mathrm{mt}$, Singapur'da kişi başına $10.3 \mathrm{mt}$ ve Tayland'da kişi başına $4.62 \mathrm{mt}$ olarak gerçekleşmiştir. Singapur dışındaki diğer ülkelerde çevre kirliliği artış eğiliminde iken, Singapur'da çevre kirliliği dalgalanmalar göstermekle birlikte 2000 yılına nazaran azalma eğilimindedir. Bununla birlikte Singapur'da diğer ülkelere kıyasla çevre kirliliği çok daha yüksek seviyelerdedir. Çevre kirliliğindeki artışlar hem insan sağlığının hem de yaşam kalitesinin bozulmasına yol açarak, hükümet bütçesi ve harcamaları üzerinde önemli bir yere sahip olan sağlık harcamalarının artmasına neden olmaktadır. Bu nedenle sağlık harcamaları ile çevre kirliliği arasındaki ilişkinin ortaya konulması ülkelerin uygulayacakları politikalar açısından da önem arz etmektedir.

\section{LITERATÜR ÖZETI}

Dünya genelinde çevre kalitesindeki artan bozulma, küresel 1sınmadaki artış ile birlikte sağlıklı yaşam üzerinde ciddi bir tehlike arz etmektedir. Özellikle fosil yakıtların tüketimi nedeniyle küresel 1sınma ve sera gazı emisyonlarının artması çevre kalitesini olumsuz yönde etkilemektedir. Fosil yakıtların yakılmasından kaynaklanan partikül, $\mathrm{SO}_{2}$ ve $\mathrm{CO}_{2}$ kirliliğe önemli ölçüde katkıda bulunmaktadır (Abdullah vd., 2016, s. 27). Bunun yanı sıra hava kirliliği ve yüksek sıcaklıklar nedeniyle bulaşıcı hastalıkların yayılımının artması da sağlıkla çevre arasındaki ilişkinin incelenmesine yol açmışırı (Zaidi ve Saidi, 2018, s. 2; Chaabouni vd, 2016, s. 184). Özellikle 1970'li y1llardan itibaren sağlik harcamalarının arz ve talep yanlı belirleyicileri üzerine çalışmalar yapılmakla birlikte, sağlık harcamalarını etkileyen önemli bir faktör olmasına rağmen çevre kirliliği birçok çalışmada ihmal edilmiştir. Bununla birlikte son yıllarda ise çevreye olan duyarlılığın etkisiyle çevre kirliliği ve sağlık harcamaları arasındaki ilişkiyi dikkate alan çalışma sayısında bir artış gözlenmektedir. Çalışmanın bu bölümünde çevre kirliliği ve sağlık harcamaları arasındaki ilişkiyi ele alan önceki çalışmalara yer verilmiştir. Bu alanda yapılan çalışmalardan bazıları aşağıda sunulmuştur.

Zaidi ve Saidi (2018)'de 26 Sahra-altı Afrika ülkesi için sağlık harcamaları ile çevre kirliliği arasındaki ilişki 1990-2015 dönemi için panel eş-bütünleşme ve panel nedensellik testi kullanılarak 
analiz edilmiştir. Çalışma sonucunda çevre kirliliği ve sağlık harcamaları ile ekonomik büyüme arasında çift yönlü bir nedensellik ilişkisi olduğu bulgusuna ulaşılmıştır.

Apergis vd.(2018b)'de ABD'de (50 eyalet) sağlık harcamaları ve çevre kirliliği ilişkisi panel ARDL yöntemi kullanılarak 1966-2009 dönemi için analiz edilmiștir. Çalıșma sonucunda sağlık hizmetlerine daha fazla harcama yapan ABD eyaletleri için $\mathrm{CO}_{2}$ emisyonunun sağlık harcamaları üzerindeki etkisinin nispeten daha güçlü olduğu bulgusuna ulaşılmıştır.

Ghorashi ve Rad (2017)'de İran ekonomisi için sağlık harcamaları ve çevre kirliliği ilişsisi panel GMM yöntemi kullanılarak 1972-2012 dönemi için analiz edilmiştir. Çalışmada çevre kirliliği ve ekonomik büyüme arasında çift yönlü bir nedensellik ilişkisi, sağlık harcamalarından ekonomik büyümeye doğru da tek yönlü bir nedensellik ilişkisi olduğu sonucuna ulaşılmıştır.

Yazdi ve Khanalizadeh (2017)'de MENA ülkeleri için sağlık harcamaları ve çevre kirliliği ilişkisi panel ARDL yöntemi kullanılarak 1995-2014 dönemi için analiz edilmiştir. Çalışma sonucuna göre gelir, $\mathrm{CO}_{2}$ ve $\mathrm{PM}_{10}$ emisyonları sağlık harcamaları üzerinde pozitif bir etkiye sahiptir.

Lu vd. (2017)'de Çin'de (30 eyalet) sağlık harcamaları ve çevre kirliliği ilişkisi iki aşamalı en küçük kareler yöntemi kullanılarak 2002-2014 dönemi için analiz edilmiştir. Çalışmada çevre kirliliğinin halk sağlığı üzerinde olumsuz bir etkiye sahip olduğu bulgusuna ulaşılmıştır.

Chaabouni vd.(2016)'da alt, üst ve orta gelirli 51 ülke için sağlık harcamaları ve çevre kirliliği ilişkisi 1995-2013 dönemi için panel GMM yöntemi kullanılarak analiz edilmiştir. Her üç ülke grubu için çevre kirliliği ve sağlık harcamaları ile ekonomik büyüme arasında çift yönlü bir nedensellik ilişkisi olduğu sonucuna ulaşılmıştır. Çalışmada ayrıca üst ve orta gelirli ülkeler için çevre kirliliğinden sağlık harcamalarına doğru tek yönlü bir nedensellik ilişkisi olduğu bulgusuna da ulaşılmıştır.

Yahaya vd. (2016)'da 125 gelişmekte olan ülke için sağlık harcamaları ve çevre kirliliği ilişkisi panel eş-bütünleşme testi kullanılarak 1995-2012 dönemi için analiz edilmiştir. Çalışma sonucuna göre $\mathrm{CO}_{2}$ (çevre kalitesi) kişi başına düşen sağlık harcamalarının güçlü bir belirleyicisidir.

Balan (2016)'da Avrupa Birliğinin 25 üye ülkesi için sağlı harcamaları ve çevre kirliliği ilişkisi panel veri analizi kullanılarak 1995-2013 dönemi için analiz edilmiştir. Çalışma sonucuna göre sağlık, eğitim ve çevre kalitesi arasında nedensellik ilişkisi bulunmaktadır.

Abdullah vd. (2016)'da Malezya örneğinde sağlık harcamaları ve çevre kirliliği ilişkisi ARDL analizi kullanılarak 1970-2014 dönemi için analiz edilmiştir. Çalışma sonucuna göre uzun dönemde GSYİH, $\mathrm{CO}_{2}$, ölüm oranı, doğurganlık oranı, $\mathrm{NO}_{2}$ ve $\mathrm{SO}_{2}$ 'nin sağlık harcamaları ile ilişkisi bulunmaktadır.

Ecevit ve Çetin (2016)'da Türkiye örneğinde ekonomik büyüme ve çevre kirliliğinin sağlık üzerindeki etkisi 1960-2011 dönemi verileri ile Johansen-Juselius ve Phillips-Ouliaris eşbütünleşme yöntemleri ile Granger nedensellik testi kullanılarak analiz edilmiştir. Çalışmada gelirin bebek ölüm oranını (sağlık kalitesi) negatif ve karbon salınımının bebek ölüm oranını ise pozitif etkilediği sonucuna ulaşılmıştır. Çalışmada ayrıca karbon salınımı ile bebek ölüm oranı arasında çift yönlü bir Granger nedensellik ilişkisi olduğu bulgusuna da ulaşılmıştır.

Assadzahed vd.(2014)'de 8 petrol ihraç eden ülke için sağlık harcamaları ve çevre kirliliği ilişkisi panel veri analizi kullanılarak 2000-2010 dönemi için analiz edilmiştir. Çalışma sonucuna göre sağlık harcamaları üzerinde gelir ve $\mathrm{CO}_{2}$ pozitif, yaşam beklentisi ise negatif bir etkiye sahiptir.

Odusanya vd. (2014)'de Nijerya örneğinde sağlık harcamaları ve çevre kirliliği ilişkisi ARDL analizi kullanılarak 1960-2011 dönemi için analiz edilmiştir. Çalışma sonucuna göre CO2 emisyonu arttıkça sağlık harcamaları hem uzun hem de kısa dönemde önemli ölçüde artmaktadır.

Yazdi vd. (2014)'te İran örneğinde sağlık harcamaları ve çevre kirliliği ilişkisi ARDL analizi kullanılarak 1967-2010 dönemi için analiz edilmiştir. Çalışma sonucuna göre sağlık harcamaları üzerinde gelir, $\mathrm{CO}$ ve $\mathrm{SO} 2$ istatistiksel olarak anlamlı ve pozitif bir etki yaratmaktadır.

Erden ve Turan Koyuncu (2014)'te Türkiye'de ekonomik kalkınma, çevre kirliliği ve insan sağlığı arasındaki ilişki 1980-2012 dönemi için VAR ve Granger nedensellik testleri kullanılarak analiz 
edilmiştir. Çalışma sonucunda ekonomik kalkınmanın karbon salınımında bir artışa neden olduğu ve bu durumun sağlık harcamalarını artırdığı bulgusuna ulaşılmıştır.

Zheng vd. (2010)'da Çin'de (31 eyalet) sağlık harcamaları ve çevre kirliliği ilişkisi panel eşbütünleșme ve panel VECM yöntemleri kullanılarak 1997-2003 dönemi için analiz edilmiștir. Çalıșma sonucuna göre hem uzun hem de kısa dönemde, kamu sağlık harcamaları sadece eyaletlerin ekonomisinden değil, aynı zamanda çevre kalitesinden de olumlu etkilenmektedir.

Narayan ve Narayan (2008)'de 8 OECD ülkesi için sağlık harcamaları ve çevre kirliliği ilişkisi panel eş-bütünleşme yöntemi kullanılarak 1980-1999 dönemi için analiz edilmiştir. Çalışma sonucuna göre gelir ve CO emisyonu sağlık harcamaları üzerinde pozitif ve istatistiksel olarak anlamlı bir etkiye sahiptir.

Jerrett vd. (2003)'te Kanada örneğinde sağl1k harcamaları ve çevre kirliliği ilişkisi iki aşamalı en küçük kareler yöntemi kullanılarak 1979-1988 ve 1990-1991 dönemleri için analiz edilmiştir. Çalışmada daha yüksek kirliliğe sahip olan şehirlerin kişi başına düşen sağlık harcamalarının daha yüksek olduğu sonucuna ulaşılmıştır.

Özetle, çevre kirliliği ve sağlık harcamaları arasındaki ilişkiyi inceleyen çalışmalarda genellikle çevre kirliliğine yol açan değişken ile sağlık harcamaları arasında pozitif bir ilişki olduğu sonucuna ulaşılmıştır. Başka bir ifadeyle çevre kirliliğindeki bir artış sağlık harcamalarında da bir artışa yol açmaktadır.

\section{VERİ VE MODEL}

Bu çalışmada sağlık harcamaları çevre kirliliği ve ekonomik büyüme arasındaki ilişki 2000-2014 dönemi yıllık verileri kullanılarak ASEAN-5 (Endonezya, Filipinler, Malezya, Singapur ve Tayland) ülkeleri için analiz edilmiştir. Çalışmada sağlık harcaması değişkeni olarak, kişi başına reel sağlık harcaması (2010 fiyatlarıyla, \$) ve çevre kirliliği değişkeni olarak $\mathrm{CO}_{2}$ değişkeni (kişi başına metrik ton) kullanılmıştır. Çevre kirliliği değişkeni olarak $\mathrm{CO}_{2}$ 'nin seçilmesinin nedenleri şu şekildedir: (i) $\mathrm{C}_{2}$ 'nin uzun süre atmosferde kalması, (ii) sera gazı oluşumuna en fazla katkıda bulunan gaz olması ve (iii) yapılan çalışmalarda $\mathrm{CO}_{2}$ ve diğer kirleticilerin $\left(\mathrm{NO}_{\mathrm{x}}\right.$ ve $\left.\mathrm{SO}_{2}\right)$ yüksek düzeyde $(\% 95)$ korele olduğu bulgusuna ulaşılmasıdır (Sileem, 2016, s. 67). Ayrıca çalışmada açıklayıcı değişken olarak ekonomik büyüme (kişi başına reel GSYİH-2010 fiyatlarıyla, \$) değişkeni kullanılmıştır. Bu çalışmadaki tüm veriler Dünya Bankası'nın (WB) Dünya Kalkınma Göstergelerinden (WDI) alınmıştır.

Sağlık harcamaları, çevre kirliliği ve ekonomik büyüme arasındaki ilişkiyi incelemek için kullanılan model eşitlik (1)'de gösterildiği gibidir:

$$
\mathrm{HE}=f\left(\mathrm{CO}_{2}, Y\right)
$$

Eşitlik (1)'de HE sağlık harcamasını, $\mathrm{CO}_{2}$ çevre kirliliğini Y ise ekonomik büyümeyi göstermektedir. Bu çalışmada kullanılan modelin panel veri olarak gösterimi eşitlik (2)'deki gibidir.

$$
\ln H E_{i t}=\alpha_{0 i}+\beta_{1 i} \ln C O 2_{i t}+\beta_{2 i} \ln Y_{i t}+\varepsilon_{i t}
$$

Çalışmada serilerin heterojenliğini azaltmak için değişkenlerin doğal logaritmaları alınmıştır. $\mathrm{Bu}$ çalışmada gelirdeki ve artan karbondioksit emisyonu vasıtasıyla çevre kirliliğindeki artışın sağlık harcamaları üzerinde pozitif bir etkiye sahip olması beklenmektedir. Zira ülke ekonomileri büyüdükçe sağlık harcamalarına daha fazla ihtiyaç duyulmakta ve uygulamalı literatürdeki çalışmalar da bu ilişkiyi desteklemektedir. Öte yandan, çevre kalitesi düştüğünde, insan sağlı̆̆ 1 olumsuz yönde etkilenmektedir. Ayrıca sağlıktaki kötüleşme sağlık üzerinde daha fazla harcama gerektirmektedir (Narayan ve Narayan, 2008, s. 369).

\section{METODOLOJİ VE UYGULAMA SONUÇLARI}

$\mathrm{Bu}$ çalışmanın uygulaması üç aşamadan oluşmaktadır. İlk olarak panel birim kök testi uygulanarak değişkenlerin durağanlık özellikleri ortaya konulacaktır. İkinci olarak panel eş-bütünleşme testleri 
uygulanarak modelde ele alınan değişkenler arasında uzun dönemli bir ilişki olup olmadığı test edilecektir. Son olarak da değişkenlere ilişkin esneklik katsayıları belirlenmeye çalışılacaktır.

Durağan olmayan değişkenler üzerine regresyonların uygulanması, değişkenler arasındaki ekonomik ilişkilerde yanıltıcı tahminlere yol açabildiğinden birim kök analizlerinin yapılması gerekmektedir (Lin ve Benjamin, 2018, s. 715). Bu çalışmada panel birim kök testi olarak Im-Pesaran-Shin (IPS2003), Fisher-ADF (Maddala-Wu,1999) ve Fisher-PP (Choi, 2001) testleri uygulanmıştır. Her üç test için de sıfır hipotezi serilerin birim köke sahip olduğunu, alternatif hipotez ise serilerin birinci fakında durağan olduğunu ifade etmektedir. Ele alınan birim kök testlerine ilişkin sonuçlara Tablo 1'de yer verilmiştir.

Tablo 1: Birim Kök Testi Sonuçları

\begin{tabular}{|c|c|c|c|}
\hline \multirow{2}{*}{ Değişkenler } & \multirow{2}{*}{ Yöntem } & \multicolumn{2}{|c|}{ Sabitli Model } \\
\cline { 3 - 4 } & & $\begin{array}{c}\text { Seviye } \\
\text { Test istatistiği } \\
\text { (olas1lik değeri) }\end{array}$ & $\begin{array}{c}\text { 1.Fark } \\
\text { Test istatistiği } \\
\text { (olas1lk değeri) }\end{array}$ \\
\hline \multirow{3}{*}{$\operatorname{lnHE}$} & IPS & $0.10454(0.5416)$ & $-3.97904(0.0000)$ \\
\cline { 2 - 4 } & Fisher-ADF & $7.33885(0.6931)$ & $34.2818(0.0002)$ \\
\cline { 2 - 4 } & Fisher-PP & $7.88066(0.6405)$ & $75.3575(0.0000)$ \\
\hline \multirow{3}{*}{$\ln Y$} & IPS & $2.26007(0.9881)$ & $-2.59628(0.0047)$ \\
\cline { 2 - 4 } & Fisher-ADF & $4.24446(0.9356)$ & $23.7576(0.0083)$ \\
\cline { 2 - 4 } & Fisher-PP & $5.12057(0.8830)$ & $53.4753(0.0000)$ \\
\hline \multirow{3}{*}{$\operatorname{lnCO}_{2}$} & IPS & $0.20406(0.5808)$ & $-3.14996(0.0008)$ \\
\cline { 2 - 4 } & Fisher-ADF & $8.37142(0.5926)$ & $28.2456(0.0016)$ \\
\cline { 2 - 4 } & Fisher-PP & $9.33726(0.5004)$ & $53.3859(0.0000)$ \\
\hline
\end{tabular}

Tablo 1'de yer alan birim kök testi sonuçları ASEAN-5 ülkeleri için sağlık harcamaları, çevre kirliliği ve ekonomik büyümenin durağan olmayan özelliklerini ortaya koymakla kalmamakta aynı zamanda panel eş-bütünleşme analizi için bir zemin oluşturmaktadır (Lin ve Benjamin, 2018, s. 715). Başka bir ifadeyle ele alınan serilere ilişkin birim kök test sonuçları I(1) olduğundan, değişkenler arasındaki uzun dönemli ilișki analiz edilebilmektedir. Bu çalışmada uzun dönemli ilişkinin ortaya konulabilmesi için iki ayrı eş-bütünleşme testi kullanılmıştır. Bu testler Pedroni (1999) ve Kao (1999) eş-bütünleşme testleridir. Belirtilen testlerin her biri, istatistiklerin hesaplanması için farklı teknikler ve varsayımlara dayandırılmakta ve eş-bütünleşmenin var olduğunu gösteren alternatif hipoteze karşı eş-bütünleşmenin olmadığını ifade eden sıfir hipotezi test edilmektedir (Zoundi, 2017, s. 1072).

Pedroni eş-bütünleşme testinde, yedi test istatistiği hesaplanarak paneldeki kesit-içi ve kesitler-arası etkilerin ortaya konulması amaçlanmaktadır. Bu eş-bütünleşme testinde yer alan yedi istatistiğin dördü kesit-içi, üçü ise kesitler-arası istatistiklerdir. Kesit içi test istatistiklerinden olan panel v istatistiği parametrik olmayan bir varyans oranı istatistiğidir. Panel rho istatistiği, Phillips ve Perron rhoistatistiğine benzeyen ve parametrik olmayan bir istatistiktir. Panel PP istatistiği parametrik olmayan ve Phillips ve Perron t istatistiğine benzeyen bir istatistiktir. Panel ADF istatistiği ise artırılmış Dickey-Fuller t-istatistiğine benzer bir parametrik istatistiktir. Kesitler-arası test istatistikleri ise, grup ortalama yaklaşımına dayanmaktadır. Grup rho istatistiği Phillips ve Perron rho istatistiğine, grup PP istatistiği Phillips ve Perron t-istatistiğine ve grup ADF ise artırılmış Dickey-Fuller t-istatistiğine benzemektedir (Pedroni, 1999, s. 658). Pedroni eş-bütünleşme testi sonuçları Tablo 2'de gösterilmiştir.

Tablo 2: Pedroni Eş-bütünleşme Testi Sonuçları

\begin{tabular}{|c|c|c|}
\hline Test İstatistiği & İstatistik (olasılık değeri) & $\begin{array}{l}\text { Ağırlıklı İstatistik } \\
\text { (olasılık değeri) }\end{array}$ \\
\hline \multicolumn{3}{|c|}{ Kesit-içi } \\
\hline Panel v & $2.308093(0.0105)$ & $2.019360(0.0217)$ \\
\hline Panel rho & $-1.093201(0.1372)$ & $-0.965696(0.1671)$ \\
\hline Panel PP & $-3.069217(0.0011)$ & $-2.838096(0.0023)$ \\
\hline Panel ADF & $-3.704831(0.0001)$ & $-3.520056(0.0002)$ \\
\hline \multicolumn{3}{|c|}{ Kesitler-aras1 } \\
\hline
\end{tabular}




\begin{tabular}{|c|l|l|}
\hline Grup rho & $-0.149839(0.4404)$ & \\
\hline Grup PP & $-4.427386(0.0000)$ & \\
\hline Grup ADF & $-4.343320(0.0000)$ & \\
\hline
\end{tabular}

Tablo 2'den de görüleceği üzere Pedroni eş-bütünleşme analizinde panel rho-istatistiği ve grup rho istatistiği dışındaki 5 istatistik değeri için eş-bütünleşmenin olmadığını ifade eden sıfır hipotezi reddedilmektedir. Sıfır hipotezinin reddedilmesinde $\% 5$ anlamlılık düzeyi dikkate alınmıştır. Dolayısıyla sağlık harcamaları, ekonomik büyüme ve çevre kirliliği arasında eş-bütünleşme ilişkisi söz konusudur. Bu durum ele alınan değişkenler arasında uzun dönemli bir ilişki olduğu ve ilgili değişkenlerin uzun dönemde birlikte hareket ettikleri anlamına gelmektedir. Bu çalışmada uygulanan bir diğer eş-bütünleşme testi olan Kao testi, Dickey Fuller (DF) ve Genişletilmiş Dickey Fuller (ADF) testleri kullanılarak panel veri analizi için bir eş-bütünleşme testi sunmaktadır. Kao eş-bütünleşme testine ilişkin sonuçlara Tablo 3'te yer verilmiştir.

Tablo 3: Kao Eş-bütünleşme Testi Sonuçları

\begin{tabular}{|c|c|c|}
\hline & t-istatistiği & Olas1lık Değeri \\
\hline ADF & -2.293291 & 0.0109 \\
\hline
\end{tabular}

Pedroni (1999) eş-bütünleşme testinde olduğu gibi, Kao Eş-bütünleşme testinde de sifır hipotezinin reddedilmesinde $\% 5$ anlamlılık düzeyi dikkate alınmıştır. Olasılık değeri 0.05 'den küçük olduğu için eş-bütünleşmenin var olduğunu ifade eden alternatif hipotez kabul edilmiştir. Kao Eş-bütünleşme testi sonuçları, Pedroni eş-bütünleşme testi sonuçlarını destekler niteliktedir. Buna göre çalışmada ele alınan üç değişken olan sağlık harcamaları, çevre kirliliği ve ekonomik büyüme arasında uzun dönemli bir ilişki söz konusudur.

Değişkenler arasında uzun dönemli bir ilişki olduğunun tespit edilmesini takiben değişkenlerin uzun dönem esneklikleri belirlenebilmektedir. Bu çalışmada değişkenlerin uzun dönem esneklerini belirlemek amaciyla otokorelasyon, değişen varyans gibi sorunlardan kaynaklanan sapmaları düzelten ve Pedroni (2000) tarafından geliştirilen FMOLS testi kullanılmıştır. Bu test Monte Carlo simülasyonuna dayandırılmakta ve küçük örneklemler için daha iyi sonuç vermektedir. FMOLS test sonuçları Tablo 4'te gösterilmiştir.

Tablo 4: Uzun Dönem Katsay1lar

\begin{tabular}{|c|c|c|c|c|}
\hline \multicolumn{5}{|c|}{ FMOLS } \\
\hline Değişkenler & Katsay1 & $\begin{array}{c}\text { Standart } \\
\text { Hata }\end{array}$ & t-istatistiği & Olasılık Değeri \\
\hline $\ln Y$ & 0.510621 & 0.102499 & 4.981736 & 0.0000 \\
\hline $\ln \mathrm{CO}_{2}$ & 0.228628 & 0.087029 & 2.627035 & 0.0108 \\
\hline
\end{tabular}

FMOLS test sonuçlarına göre hem çevre kirliliği hem de ekonomik büyüme sağlık harcamalarını pozitif yönde etkilemektedir. Başka bir ifadeyle, hem ekonomik büyümedeki hem de çevre kirliliğindeki artışlar sağlık harcamalarında bir artışa yol açmaktadır. Buna göre ekonomik büyümedeki \%1'lik bir artış, sağlık harcamalarını \%0.51 artırırken, çevre kirliliğindeki \%1'lik bir artış sağlık harcamalarında yaklaşı \%0.23'lük bir artışa yol açmaktadır. Değişkenlere ilişkin katsayılar \%5 önem düzeyinde istatistiksel olarak anlamlıdır. Diğer yandan gelir esnekliği katsayısının (0.51) 1'den küçük olması analize dâhil edilen ülkelerde sağl1k hizmetlerinin zorunlu mal olduğunu göstermekte ve bu hizmetlerin sağlanmasında devlet müdahalesinin gerekliliğini ortaya koymaktadır.

\section{SONUÇ VE ÖNERI}

Ülkeler geliştikçe, sanayileşmenin bir sonucu olarak çevre kirliliği artmakta, sağlik ile ilgili yaşam kalitesi bozulmakta ve dolayısıyla sağlık harcamalarında da bir artış meydana gelmektedir. Çevre kirliliğinin artmasının insan sağlığı üzerindeki olumsuz etkisi işgücü verimliliğinin azalması ve ekonomik büyümenin bu durumdan olumsuz etkilenmesidir. Bu çalışmada sağlık harcamaları, çevre kirliliği ve ekonomik büyüme ilişkisi ASEAN-5 ülkeleri için panel birim kök ve panel eş-bütünleşme testleri uygulanarak incelenmiştir. Uygulama sonuçları sağlık harcamaları, çevre kirliliği ve ekonomik büyüme arasında eş-bütünleşme ilişkisinin varlığını ortaya koymaktadır. Ayrıca bu çalışmada çevre kirliliğinin ve ekonomik büyümenin sağlık harcamalarını artırdığı bulgusuna ulaşılmıştır. Çalışmada 
elde edilen bulgular Yazdi ve Khanalizadeh (2017), Lu vd. (2017), Yazdi vd. (2014) ile Narayan ve Narayan (2008) ile uyumludur.

Belirtilen çerçevede ASEAN-5 ülkeleri genelinde karbondioksit emisyonunu azaltmaya yönelik politikaların (çevresel atıkların azaltılması, fosil yakıtlara ilişkin enerji tasarrufunun sağlanması, enerji verimliliğinin artırılması, yenilenebilir enerji kaynaklarının kullanımının artıılması gibi) sağlık ile ilgili faydalar sağlayabileceği söylenebilir. Örneğin, yapılması planlanan yenilenebilir enerji yatırımları, ekonomik büyümeyi pozitif yönde etkileyebilmekle birlikte, karbondioksit emisyonunun düşürülmesine yol açarak sağlık üzerindeki olumsuz etkinin azalmasına katkıda bulunabilir. Diğer taraftan, bu çalışmada elde edilen sonuçlar ASEAN-5 ülkeleri için sağlık politikasının çevre kirliliğini de içermesi gerekliliğini ortaya koymaktadır. Bu durumun dikkate alınmaması halinde sağlık harcamalarında bir artış söz konusu olabilmektedir.

\section{KAYNAKÇA}

Abdullah, H., Azam, M. ve Zakariya, S. K. (2016). The impact of environmental quality on public health expenditure in Malaysia. Second Asia Pacific Conference on Advanced Research (APCAR), Melbourne, February, 27-40.

Akram, N., Padda, H. ve Khan, M. (2008). The long term impact of health on economic growth in Pakistan. The Pakistan Development Review, 47(4), 487-500.

Apergis, N., Gupta, R., Lau, C. K. M. ve Mukherjee, Z. (2016). An analysis of the relationship between U.S. state level carbon dioxide emissions and health care expenditure. University of Pretoria Department of Economics Working Paper Series, 1-31.

Apergis, N., Gupta, R., Lau, C. K. M. ve Mukherjee, Z. (2018b). U.S. state-level carbon dioxide emissions: does it affect healthcare expenditure? Renewable and Sustainable Energy Reviews, 91, 521-530.

Apergis, N., Jebli, M. B. ve Youssef, S. B. (2018a). Does renewable energy consumption and health expenditures decrease carbon dioxide emissions? Evidence for Sub-Saharan Africa Countries. Renewable Energy, 127, 1011-1016.

Assadzadeh, A., Bastan, F. ve Shahverdi, A. (2014). The impact of environmental quality and pollution on health expenditures: A case study of petroleum exporting countries. Proceedings of 29th International Business Research Conference, 24 - 25 November 2014, Sydney, Australia.

Balan, F. (2016). Environmental quality and its human health effects: A causal analysis for the EU25". International Journal of Applied Economics, 13(1), 57-71.

Chaabouni, S., Zghidi, N. ve Mbarek, M. B. (2016). On the causal dynamics between CO2 emissions, health expenditures and economic growth. Sustainable Cities and Society, 22, 184-191.

Choi, I. (2001). Unit root tests for panel data. Journal of International Money and Finance, 20, 249272.

Ecevit, E. ve Çetin, M. (2016). Ekonomik büyüme ve çevre kirliliğinin sağlik üzerindeki etkisi: Türkiye ile ilgili ampirik kanıt. Erciyes Üniversitesi İktisadi ve İdari Bilimler Fakültesi Dergisi, 48, 83-98.

Erden, C. ve Turan Koyuncu, F. (2014). Kalkınma ve çevresel sağlık riskleri: Türkiye için ekonometrik bir analiz. Aksaray Üniversitesi İktisadi ve İdari Bilimler Fakültesi Dergisi, 6(2), 9-23.

Fifth ASEAN State of the Environment Report (2017). 1-252.

Im, K. S., Pesaran, M. H. ve Shin, Y. (2003). Testing for unit roots in heterogeneous panels. Journal of Econometrics, 115(1), 53-74.

Jerrett, M., Eyles, J., Dufournaud, C. ve Birch, S. (2003). Environmental influences on healthcare expenditures: An exploratory analysis from Ontario, Canada. J. Epidemiol Community Health, $57,334-338$. 
Kao, C. (1999). Spurious regression and residual-based tests for cointegration in panel data. Journal of Econometrics, 90, 1-44.

Lin, B. ve Benjamin, I. N. (2018). Causal relationships between energy consumption, foreign direct investment and economic growth for MINT: Evidence from panel dynamic ordinary least square models. Journal of Cleaner Production, 197, 708-720.

Lu, Z. N., Chen, H., Hao, Y., Wang, J., Song, X. ve Mok, T. M. (2017). The dynamic relationship between environmental pollution, economic development and public health: Evidence from China. J. Clean. Prod., 166, 134-147.

Maddala, G. S. and Wu, S. (1999). A comparative study of unit root tests with panel data and a new simple test. Oxford Bulletin of Economics and Statistics, 61(1), 631-652.

Murthy, V. N. R. ve Okunade, A. A. (2016). Determinants of U.S. health expenditure: Evidence from autoregressive distributed lag (ARDL) approach to cointegration, Economic Modelling, 59, 6773.

Narayan, P. K. ve Narayan, S. (2008). Does environmental quality influence health expenditures? Empirical evidence from a panel of selected OECD Countries. Ecological Economics, 65, 367374.

Narayan, S., Narayan, P. K. ve Mishra, S. (2010). Investigating the relationship between health and economic growth: Empirical evidence from a panel of 5 Asian Countries. Journal of Asian Economics, 21, 404-411.

Odusanya, I. A., Adegboyega, S. B. ve Kuku, M. A. (2014). Environmental quality and health care spending in Nigeria. Fountain Journal of Management and Social Sciences, 3(2), 57-67.

Pedroni, P. (1999). Critical values for cointegration tests in heterogeneous panels with multiple regressors. Oxford Bulletin of Economics and Statistics, 61(1), 653-670.

Pedroni, P. (2000). Fully-modified OLS for heterogeneous cointegrated panels. Advances in Econometrics, 15, 93-130.

Remoundou, K. ve Koundouri, P. (2009). Environmental effects on public health: An economic perspective. International Journal Environment Research and Public Health, 6, 2160-2178.

Sagarik, D. (2016). Determinants of health expenditures in ASEAN Region: Theory and evidence. Millennial Asia, 7(1) 1-19.

Selim, S., Uysal D. ve Eryiğit, P. (2014). Türkiye'de sağlık harcamalarının ekonomik büyüme üzerindeki etkisinin ekonometrik analizi. Niğde Üniversitesi İktisadi ve İdari Bilimler Fakültesi Dergisi, 7(3), 13-24.

Sileem, H. H. M. (2016). Health expenditure, climate changes and corruption in the MENA Region: A Granger causality approach. Journal of African Development, 18(2), 61-72.

Yahaya, A., Nor, N. M., Habibullah, M. S., Ghani, J. A. ve Noo, Z.M. (2016). How relevant is environmental quality to per capita health expenditures? Empirical Evidence from Panel of Developing Countries" Springer Plus, 5(925), 1-14.

Yazdi, S. K. ve Khanalizadeh, B. (2017). Air pollution, economic growth and healthcare expenditure. Economic Research-EkonomskaIstraživanja, 30(1), 1181-1190.

Yazdi, S. K., Tahmasebi, Z. ve Mastorakis, N. (2014). Public healthcare expenditure and environmental quality in Iran. Recent Advances in Applied Economics, 126-134. 2 Haziran 2019 tarihinde

https://www.researchgate.net/publication/308760974_Public_Healthcare_Expenditure_and_Envir onmental quality in Iran adresinden erişildi. 
Zaidi, S. ve Saidi, K. (2018). Environmental pollution, health expenditure and economic growth and in the Sub-Saharan Africa Countries: Panel ARDL approach. Sustainable Cities and Society, 41, 833-840.

Zheng, X., Yu, Y., Zhang, L. ve Zhang, Y., (2010). Does pollution drive up public health expenditure? A panel unit root and cointegration analysis. 2 Haziran 2019 tarihinde http://images.ruc.edu.cn/other/2010-05-20/1274338288347.pdf adresinden erişildi.

Zoundi, Z. (2017). CO2 Emissions, renewable energy and the environmental kuznets curve, a panel cointegration approach. Renewable and Sustainable Energy Reviews, 72, 1067-1075. 